\title{
Approach for Assessing Direct Flood Damages
}

\author{
Lenka Gaňová ${ }^{1}$, Martina Zeleňáková ${ }^{1}$, Daniel Słyś ${ }^{2}$, Pavol Purcz ${ }^{3}$ \\ ${ }^{1}$ Technical University of Košice, Faculty of Civil Engineering, Institute of Environmental Engineering \\ ${ }^{2}$ Rzeszów University of Technology, Department of Infrastructure and Sustainable Development \\ ${ }^{3}$ Technical University of Košice, Faculty of Civil Engineering, Institute of Construction Technology and \\ Management \\ e-mail: lenka.ganova@tuke.sk,martina.zelenakova@tuke.sk,daniels@prz.edu.pl,pavol.purcz@tuke.sk
}

\begin{abstract}
This article presents a methodological approach to flood direct tangible damage - damage to assets and direct intangible damage - environmental damage and loss of life assessment. The assessment of flood risk is an essential part of the risk management approach, which is the conceptual basis for the EU directive 2007/60/ES on the assessment and management of flood risk. The purpose of this directive is to establish a framework for the assessment and management of flood risk, aiming at the reduction of the adverse consequences for human health, the environment, cultural heritage and economic activity associated with flood in the community. Overall, an accurate estimation of negative effects on assets, environment and people is important in order to be able to determine the economy, environmental and social flood risk level in a system and the effects of risk mitigation measures.
\end{abstract}

Key words: flood, direct tangible damage, direct intangible damage, flood risk

\section{Introduction}

In the last decade, Slovakia is increasingly affected by floods. These floods have been recorded in substantial material damage and there are exceptional cases of loss of human life. Therefore, it is important to have insight into the possible consequences and risks of flooding [1].

Flood losses can be classified into direct and indirect losses. Direct losses are those which occur due to the physical contact of the flood water with humans, property or any other objects. Indirect losses are induced by a flood, but occur, in space or time, outside the actual event. Usually, both types of losses are further classified into tangible and intangible damage, depending on whether or not they can be assessed in monetary value [2].

Examples for the different types of damage are [3]: 
- Direct, tangible: damage to private buildings and contents; destruction of infrastructure such as roads, railroads; erosion of agricultural soil; destruction of harvest; damage to livestock; evacuation and rescue measures; business interruption inside the flooded area; clean-up costs.

- Direct, intangible: loss of life; injuries; loss of memorabilia; psychological distress, damage to cultural heritage; negative effects on ecosystems.

- Indirect, tangible: disruption of public services outside the flooded area; induced production losses to companies outside the flooded area (e.g. suppliers of flooded companies); cost of traffic disruption; loss of tax revenue due to migration of companies in the aftermath of floods.

- Indirect, intangible: trauma; loss of trust in authorities.

Although flood damage assessment is an essential part of flood risk management, it has not received much scientific attention. The consideration of flood damage within the decisionmaking process of flood risk management is still relatively new.

In this paper methodological approach to flood direct tangible damage (damage to assets) and direct intangible damage (environmental damage and loss of life) assessment is presented. Overall, an accurate estimation of direct damage is important in order to be able to determine the risk level in a system, that consider these damage as consequences and the effects of risk reducing measures.

\section{Methodology for the estimation damage}

\subsection{Damage to assets}

Method for evaluation of flood damage to assets is based on approach using object-orientated land use information, an estimation of values of assets at risk per metre or cubic metre and kind of relative damage function [4]. The method is focusing on the evaluation of direct, tangible damage and all kind of infrastructure include streets, railways, bridges, etc..

The total flood damage to assets is expressed as (1) [4]:

$$
D=\sum D_{i k}
$$

where: $\quad D \quad$ total damage to assets $[€]$,

$$
D_{\mathrm{ik}} \quad \text { damages to each category }[€] \text {. }
$$

The formula for the estimation of damages to each category is (2) [4]:

$$
D_{i k}=Q_{i k} C_{k} L_{k}
$$

where: $\quad k \quad$ category of tangible elements at risk ( $k$ possible categories),

$i \quad$ entity in a elements at risk category,

$Q \quad$ size or number of affected assets by category $\left[\mathrm{ks}, \mathrm{m}, \mathrm{m}^{2}, \mathrm{~m}^{3}\right]$,

$C \quad$ price of affected assets by category $\left[€ / \mathrm{ks} ; € / \mathrm{m} ; € / \mathrm{m}^{2} ; € / \mathrm{m}^{3}\right]$,

$L \quad$ percentage of damage to assets (according to damage function) [-]. 


\subsection{Environmental damage}

In this section methodological approach to flood direct intangible damage - negative effects on environment assessment is presented. Overall, an accurate estimation of negative effects on environment is important in order to be able to determine the environmental flood risk level in a system and the effects of risk mitigation measures.

Consequences are determined based on the categorization of potential sources of pollution which affect water quality in case of flooding. Sources of pollution are divided into two groups: point and diffuse sources of pollution (Table 1).

Table 1: Sources of pollution

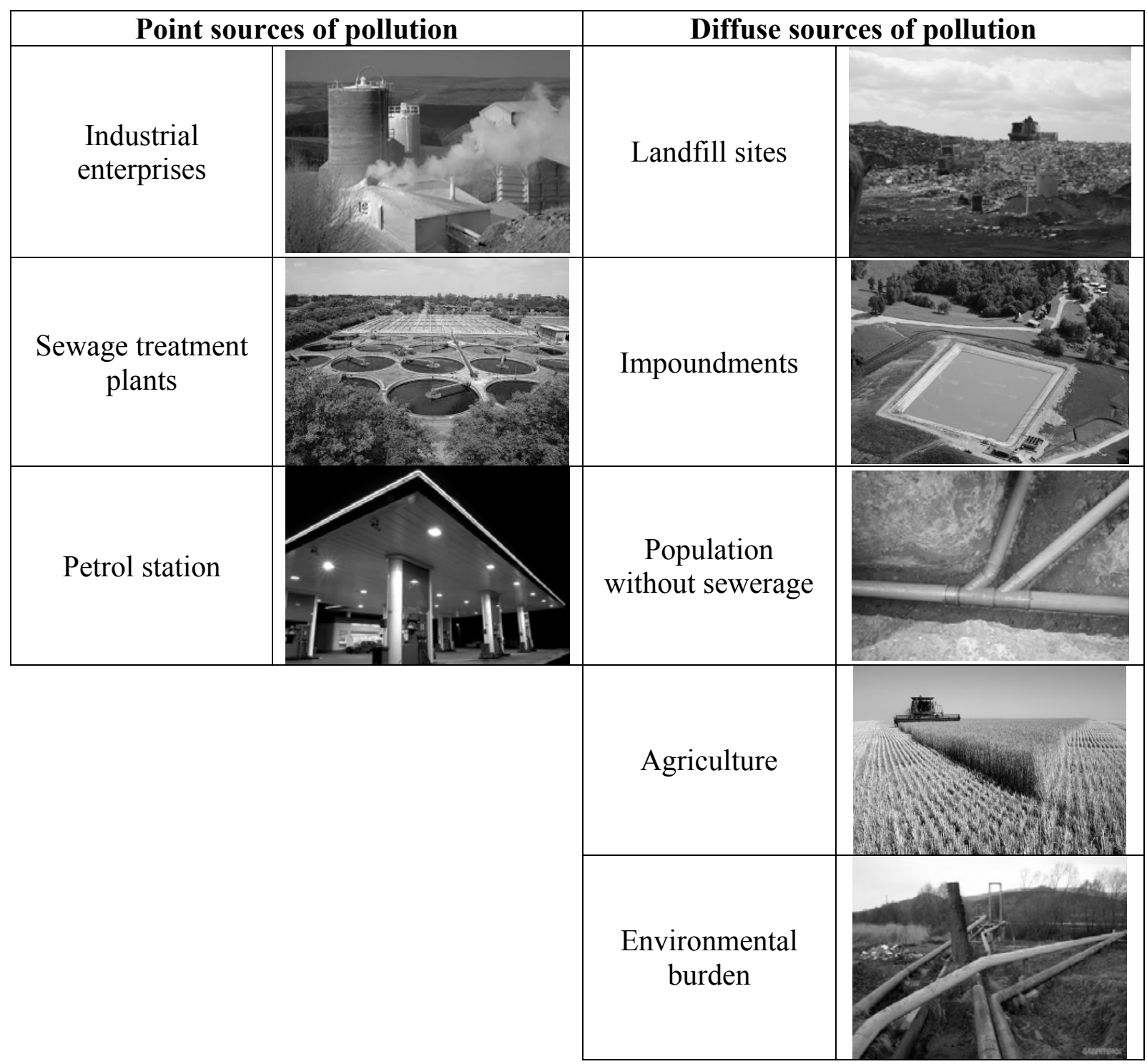


Flooding of mentioned sources of pollution may leak out pollutants and thus deteriorate the quality of surface water, groundwater, and soils, which can lead to environmental disasters, such as damage of habitats, fauna and flora as well as diseases and epidemics occurrence.

Table 2 gives information about importance of source (range from 1 to 5) and weight of source's category, stated by authors. The inverse ranking was applied to these sources of pollution: the least important $=1$, next least important $=2$, etc. The more dangerous source of pollution has the higher point importance. Each source was divided into categories based on literature studying, consultation and experiences. The purpose of the categories of sources of pollution weighting is to express the importance of each category relative to the other category. The more important categories had the greater weight in the overall evaluation. This classification shall enter into a narrative or numeric character, as shown in Table 2.

Table 2: Importance of source pollution, category of source and its weight

\begin{tabular}{|c|c|c|c|c|}
\hline $\begin{array}{l}\text { Source of } \\
\text { pollution }\end{array}$ & $\begin{array}{l}\text { Importance } \\
\text { of source }\end{array}$ & Characteristic & Category of source & Weight \\
\hline \multicolumn{5}{|c|}{ Point sources of pollution } \\
\hline \multirow{3}{*}{$\begin{array}{l}\text { Industrial } \\
\text { enterprises }\end{array}$} & \multirow{3}{*}{5} & \multirow{3}{*}{$\begin{array}{l}\text { Category of } \\
\text { enterprise }\end{array}$} & unclassified & 0.2 \\
\hline & & & $\mathrm{A}$ & 0.3 \\
\hline & & & B & 0.5 \\
\hline \multirow{4}{*}{$\begin{array}{l}\text { Sewage } \\
\text { treatment } \\
\text { plants }\end{array}$} & \multirow{4}{*}{5} & \multirow{4}{*}{$\begin{array}{l}\text { Number of } \\
\text { equivalent } \\
\text { inhabitants }\end{array}$} & $<2000$ & 0.14 \\
\hline & & & $2000-10000$ & 0.21 \\
\hline & & & $10000-100000$ & 0.29 \\
\hline & & & 100000 and more & 0.38 \\
\hline Petrol stations & 3 & - & - & 1 \\
\hline \multicolumn{5}{|c|}{ Diffuse sources of pollution } \\
\hline \multirow{3}{*}{ Landfills } & \multirow{3}{*}{5} & \multirow{3}{*}{ Type of landfill } & for inert waste & 0.12 \\
\hline & & & for non-hazardous waste & 0.29 \\
\hline & & & for hazardous waste & 0.59 \\
\hline Impoundments & 3 & - & - & 1 \\
\hline \multirow{3}{*}{$\begin{array}{l}\text { Population in } \\
\text { urban areas }\end{array}$} & \multirow{3}{*}{4} & \multirow{3}{*}{$\begin{array}{c}\text { Percentage of } \\
\text { population without } \\
\text { sewerage }\end{array}$} & $0-40 \%$ & 0.12 \\
\hline & & & $40-60 \%$ & 0.29 \\
\hline & & & $60-100 \%$ & 0.59 \\
\hline \multirow{3}{*}{ Agriculture } & \multirow{3}{*}{3} & \multirow{3}{*}{$\begin{array}{c}\text { Percentage of } \\
\text { potentially flooded } \\
\text { area }\end{array}$} & $0-40 \%$ & 0.12 \\
\hline & & & $40-60 \%$ & 0.29 \\
\hline & & & $60-100 \%$ & 0.59 \\
\hline \multirow{3}{*}{$\begin{array}{l}\text { Environmental } \\
\text { burden }\end{array}$} & \multirow{3}{*}{3} & \multirow{3}{*}{-} & is likely & 0.29 \\
\hline & & & is confirmed & 0.59 \\
\hline & & & is reclaimed & 0.12 \\
\hline
\end{tabular}

The overall consequence defines a negative impact on the environment and is calculated as the sum of points assigned to each source of pollution located in the floodplains (in the $Q_{\mathrm{N}}$ probability of flooding) multiplied by its weight according Table 2 . 
Consequence's rates (Table 3) were divided using Box plot method. The Box plot method is based to creating so-called Box graph. There are 4 groups created by this method. Each of the group has the identical number of the data and in mathematical statistic it is called as a quartile [5].

Table 3: Consequence's rates

\begin{tabular}{|c|c|c|c|}
\hline $\begin{array}{c}\text { Consequence } \\
\text { rate }\end{array}$ & $\begin{array}{c}\text { Scale of } \\
\text { consequence }\end{array}$ & $\begin{array}{c}\text { Consequence } \\
\text { acceptability }\end{array}$ & Significance of consequence \\
\hline 1 & $0-6.85$ & marginal & Minimal or no degradation of environment \\
\hline 2 & $6.86-12.25$ & minor & $\begin{array}{c}\text { Disruption of biological communities, } \\
\text { which are reversible and limited in time } \\
\text { and space, or the number of affected } \\
\text { individuals / populations. }\end{array}$ \\
\hline 3 & $12.26-17.65$ & intermediate & $\begin{array}{c}\text { Disruption of biological communities that } \\
\text { are widespread but reversible or in limited } \\
\text { severity. }\end{array}$ \\
\hline 4 & $17.66-25.03$ & major & $\begin{array}{c}\text { Extensive biological and physical } \\
\text { disturbance of entire ecosystems, } \\
\text { communities or whole species that persists } \\
\text { over time, or is not readily reversible. }\end{array}$ \\
\hline
\end{tabular}

Value of the resulted consequence is considered as a threat of environmental pollution during floods from all sources of pollution in the flooded area.

\subsection{Loss of life}

In an international context, various methods have been developed for loss of life estimation for different types of floods. The considered fields include dam breaks floods, tsunamis, coastal storm surges and river floods [6], [7].

In order to develop a model for loss of life estimation, it is necessary to have insight in the factors that determine loss of life. We take into account two factors - number of people exposed and damage to assets. By combining these two main elements loss of life can be estimated as is shown in the next part of the paper.

As a first step in the evaluation of $L O L$ it is important to know the number of people exposed, flood damage and number of fatalities in the last flood events. We use information about flood situations in the Slovak republic since year 2002 up to year 2012. The main source of information was report on floods published by Ministry of the Environment every year.

Based on available event statistics the model for the estimation of loss of life (LOL) caused by the flooding is proposed. The model is primarily developed for the Slovak republic.

The relationship between loss of life and other consequence categories specifically flood damage and exposed people are shown in figure 1 and 2. 


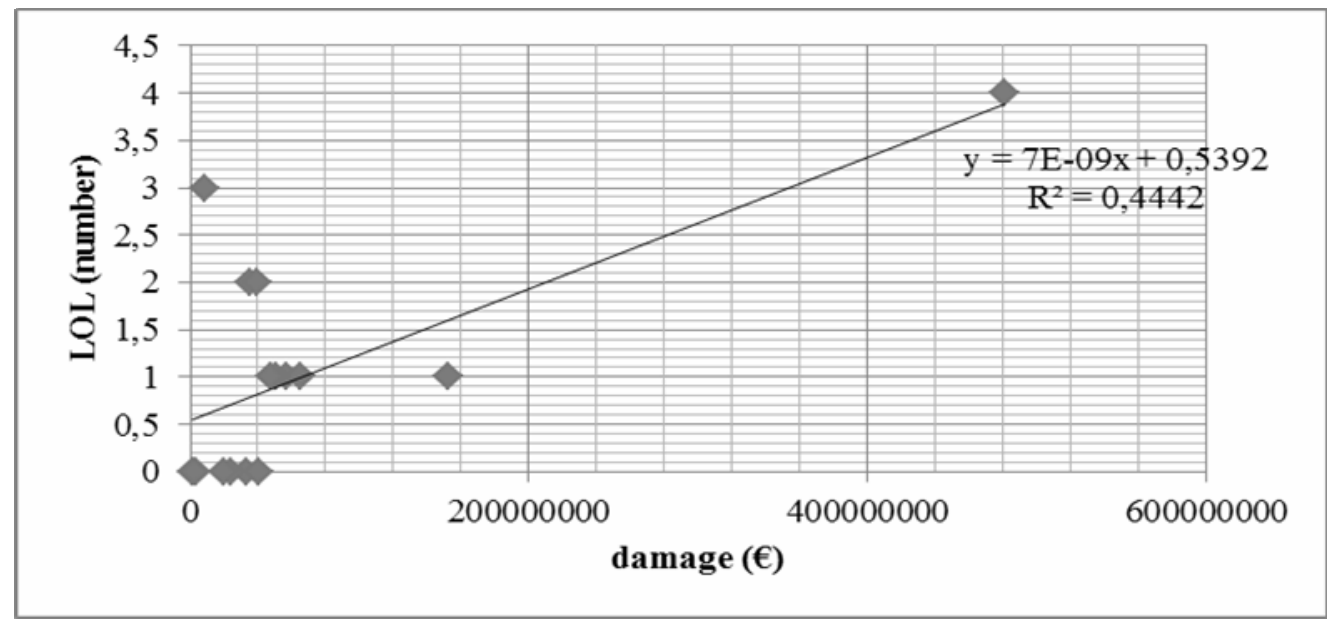

Figure 1: Correlation of flood damage and loss of life

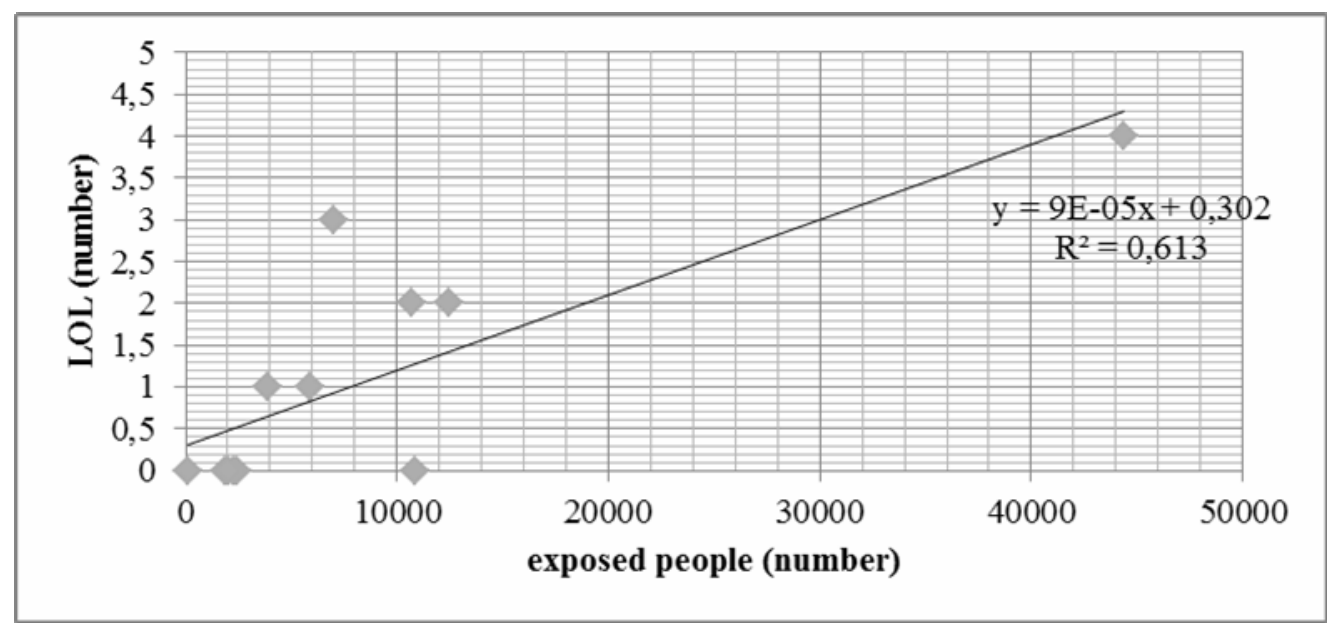

Figure 2: Correlation of exposed people and loss of life

According previous analyzing of correlation, stepwise multiple regression was used to identify following equation for loss of life (3):

$$
L O L=0,00017 x_{1}+(-0,00752) x_{2}+0,078073
$$

where: $\quad L O L \quad$ loss of life (number),

$x_{1} \quad$ number of exposed people,

$x_{2} \quad$ damage to assets (mil.€).

The outcomes of the proposed method for loss of life estimation are compared with observations from some historical flood events. Table 3 shows a comparison of the calculating $L O L$ according to equation (3) with the actual number of fatalities in analyzed flood events 2002-2012. 
Table 3: Comparison of the calculating LOL according to equation (3) with the actual number of fatalities in analyzed flood events

\begin{tabular}{|c|c|c|c|c|c|c|}
\hline Year & $\begin{array}{c}\text { Real } \\
\text { LOL } \\
\text { (number) }\end{array}$ & $\begin{array}{c}\text { Flood } \\
\text { damage } \\
\text { (mil. } \mathbf{~})\end{array}$ & $\begin{array}{c}\text { Number of } \\
\text { exposed } \\
\text { people }\end{array}$ & $\begin{array}{c}\text { Calculating } \\
\text { LOL } \\
\text { (number) }\end{array}$ & $\begin{array}{c}\text { Absolute } \\
\text { error } \\
\text { (-) }\end{array}$ & $\begin{array}{c}\text { Relative } \\
\text { error } \\
\text { (\%) }\end{array}$ \\
\hline 2002 & 1 & 50.644 & 5881 & 0.698 & -0.302 & \\
2003 & 0 & 1.457 & 1844 & 0.381 & 0.381 & \\
2004 & 2 & 34.913 & 12434 & 1.931 & -0.069 & \\
2005 & 0 & 24.046 & 2411 & 0.308 & 0.308 & \\
2006 & 1 & 47.898 & 3927 & 0.386 & -0.614 & \\
2007 & 0 & 3.637 & 2277 & 0.438 & 0.438 & \\
2008 & 2 & 39.617 & 10742 & 1.608 & -0.392 & \\
2009 & 3 & 8.417 & 6998 & 1.205 & -1.795 & \\
2010 & 4 & 480.851 & 44380 & 4.014 & 0.014 & \\
2011 & 0 & 20.1 & 2029 & 0.272 & 0.272 & \\
2012 & 0 & 2.435 & 140 & 0.083 & 0.083 & \\
\hline$\Sigma$ & 13 & & & 11.324 & -1.676 & 12.881 \\
\hline average & 1.182 & & & 1.029 & -0.152 & 12.881 \\
\hline
\end{tabular}

The table 3 shows that the proposed equation (3) correlates very well with the real values of the $L O L$ - column absolute error, where only in one case the difference is greater than 1. Because the more data in column $L O L$ is 0 , it is not possible to mathematically calculate the relative errors for each line separately, the error was determined only for average. This fact is documented in the last column of the table 1, the average relative error is less than $13 \%$.

Comparison of the outcomes of the proposed method with information from analysed flood events shows that it gives an accurate approximation of the number of observed fatalities during these events.

\section{Conclusion}

Flood risk management puts a much stronger emphasis on flood risk, where risk is defined as damage that occurs or will be exceeded with a certain probability in a certain time period (e.g. one year) [8], [9], [10]. Hence, damage aspects need to be taken into account in any deliberations on flood risk management [3]. Based on available or readily derivable information, such as records and studies on long term developments, in particular impacts of climate change on the occurrence of floods, a preliminary flood risk assessment shall be undertaken to provide an assessment of potential risks [11].

Practical application of flood risk assessment still has some problems. One of them is that environmental and social flood risk is often neglected.

The methodological framework presented in this paper tries to tackle environmental, social and economical damages caused by flood. Methodology has been proposed for the estimation of the expected annual average negative consequences of flooding where negative consequences covers economical, environmental and social consequences. These results can be used as input for the 
risk assessment and for decision-making regarding flood protection measures. Proposal for flood protection measures are fully devoted to the management of flood risk [12], [13].

\section{Acknowledgements}

The contribution is written thanks to support of project VEGA 1/0609/14.

\section{References}

[1] Zeleňáková, M. (2010). Geographical approach to flood risk analysis. In Proc. from International scientific conference: People, buildings and environment 2010. Brno: CERM, pp. 442-447.

[2] Thieken, A., Müller, M., Kreibich, H. \& Merz, B. (2005). Flood damage and influencing factors: New insights from the August 2002 flood in Germany. Water resources research, 41, 116. DOI 10.1029/2005WR004177.

[3] Mercz, B., Kreibich, H., Schwarze, R. \& Thieken, A. (2010). Review article "Assessment of economic flood damage". Nat. Hazards Earth Syst. Sci., 10, 1697-1724. DOI 10.5194/nhess10-1697-2010

[4] Horský, M. (2008). Methods of evaluation of potential flood damage and their application by means of GIS. Dissertation. Praha, p. 124.

[5] AP STATISTICS: Boxplots. Available at: http://stattrek.com/ap-statistics-1/boxplot.aspx

[6] Jonkman, S.M., Vrijling, J.K. \& Vrouwenvelder, A.C.W.M. (2008). Methods for the estimation of loss of life due to floods: a literature review and a proposal for a new method. Nat. Hazard, 46, 353-389. DOI 10.1007/s11069-008-9227-5

[7] Jonkman, S.N. (2007). Loss of life estimation in flood risk assessment. Theory and applications. Disertation. Delft University of Technology, p. 360.

[8] Directive 2007/60/EC of the European parliament and of the Council of 23 October 2007 on the assessment and management of flood risks.

[9] Act no. 7/2010 of Slovak republic on the flood protection.

[10] DEFRA (Department for Environment, Food \& Rural). (2000). Guidelines for environmental risk assessment and management. London.

[11] Zeleňáková, M. (2009). Preliminary flood risk assessment in the Hornád watershed. In River Basin Management 5 : Fifth International conference on River Basin Management including all aspects of Hydrology, Ecology, Environmental, Management, Flood plains and Wetlands, Ramla Bay Resort, Malta. Southampton: Wessex Institute of Technology, p. 15-24.

[12] Šlezingr, M. (2009). Reasons of the revitalization of watercourses. Selected Scientific Papers, 4(1), 69-80.

[13] Korytárová, J., Šlezingr, M., Uhmannová, H. (2007). Determination of potential damage to representatives of real estate property in areas afflicted by flooding. Journal of Hydrology and Hydromechanics, 55(4), p. 282-285. 